\title{
Towards Authenticity: Greece in Modern Architecture since 1900
}

\author{
By Macarena de la Vega de León*
}

In his Modern Architecture since 1900 (1982) William J.R. Curtis attempts to present a "balanced, readable overall view of the development of modern architecture from its beginning until the recent past" and to include the architecture of the non-western world, a subject overlooked by previous histories of modern architecture. Curtis places authenticity at the core of his research and uses it as the criterion to assess the historicity of modern architecture. While the second edition (1987) of Curtis' book appeared with just an addendum, for the third edition (1996) he undertook a full revision, expansion and reorganization of the content. This paper proposes that Curtis presented a more 'authentic' account of the development of modern architecture in other parts of the world with the third edition of his book. In the first edition of Modern Architecture since 1900, Greece appears only as inspiration to the work of Le Corbusier: the Acropolis is regarded as having made the greatest impression in the memory of the modern master. It is not until the third edition that Curtis discusses Greek modern architecture, embodied in the work of Dimitris Pikionis in the late 1930s and later on in the 1950s. It is also not until the 1996 edition that Greece is 'authentically' addressed in terms of 'national identity', 'universalism' or 'regionalism'. Between the first and the third editions of the book, regionalism in architecture was debated and framed in seminal essays and conferences by Curtis himself, Paul Rudolph and Kenneth Frampton. Focusing the attention on the example of Greek architecture, this paper will seek to discern developments in Curtis' discourse on regionalism between all of Modern Architecture since 1900 from inspiration to authenticity.

\section{Curtis' Discourse on Modern Architecture}

William J.R. Curtis's Modern Architecture since 1900 aimed to bridge a gap detected in previous histories of modern architecture. Like any other historian, one could argue. First published in 1982, the book's life, its editions and reprints, is unusual. A second edition appeared in 1987 with a preface and an addendum entitled "The Search of Substance: Recent World Architecture (1987)". Almost a decade after it was published; in 1996, the content was massively revised, expanded and redesigned prior to the release of the third edition of Modern Architecture since 1900. It is different from other histories of modern architecture which have been merely updated with extra chapters at the end. The fact that Curtis undertook a vast revision of the content of his book allows detection and analysis of the changes introduced in 1996, which at the same time are what the first edition was lacking. Modern Greek architecture exemplifies the shift between the two editions. This paper

${ }^{*} \mathrm{PhD}$ Candidate, Centre for Creative and Cultural Research, University of Canberra, Australia. 
proposes that Curtis presented a more complete and 'authentic' account of the development of modern architecture in other parts of the world, in general, and in Greece in particular, with the third edition of the book.

In the years separating both editions, Curtis deepened his understanding and reflection on the notion of regionalism. Interestingly, it was precisely the time when other critics and historians like Kenneth Frampton and Paul Rudolph were also publishing their reflections. Curtis searches for an 'authentic regionalism' whereas Frampton coins the more successful notion of 'critical regionalism'. Although Greece was not included in those papers as an example of regionalism, the notion, and how it developed, is the key to analysing most of the additions and changes that Curtis introduced in the third edition of Modern Architecture. In focusing on the example of modern Greek architecture and the way it is presented in terms of regionalism, this paper seeks to discern developments in Curtis' discourse on modern architecture between the first and the third editions of Modern Architecture since 1900: from inspiration to authenticity.

However, first, it is important to highlight that the subsequent impact of Curtis' Modern Architecture as a key academic text book was the result not only of the different editions and reprints, but also of the book's translations into several other languages. The first translation into Spanish, La arquitectura moderna desde 1900 appeared as early as 1986, even before the second English edition. Twenty years passed before an entirely new Spanish edition appeared in 2006, having been retranslated from the third edition of the book. The translations into German and Japanese were made soon after the publication of the first Spanish edition, in 1989 and 1990 respectively. Interestingly, the title of the first German edition, Architektur im zwanzigsten Jahrhundert, was changed in 2002 to Moderne Architektur seit 1900, again retranslated from the third edition. L'architettura moderna del Novecento, which was the translation into Italian of the book's third edition, was published in 1999. In 2004 Phaidon published the French version, L'architecture moderne depuis 1900. Finally, in 2008 Curtis' book was translated into Portuguese as Arquitetura moderna desde 1900. ${ }^{1}$ As is the case with the English editions, these translations have been repeatedly reprinted over the last thirty years -by 2013 it had already been reprinted nineteen times- resulting in the book's having a global impact. However, there has not yet been any translation into Chinese.

1. William Curtis, La arquitectura moderna desde 1900 (Madrid: Hermann Blume, 1986.) Translated by Jorge Sainz Avia. La arquitectura moderna desde 1900 (Madrid: Hermann Blume, 2006.) Translated by Jorge Sainz Avia. Kajima Shuppankai (Tokyo: 1990.) Translated by Tomoko Goto, Akira Sawamura and Kaoru Suehiro. Architektur im zwanzigsten Jahrhundert (Stuttgart: Deutsche Verlags-Anstalt, 1989.) Translated by Antje Pehnt. Moderne Architektur seit 1900 (Berlin: Phaidon Press Limited, 2002.) L'architettura moderna del Novecento (Milan: Bruno Mondadori, 1999.) Translated by Anna Barbara and Chiara Rodriquez. L'architecture modern depuis 1900 (Paris: Phaidon Press Limited, 2004.) Translated by Jacques Bosser and Philippe Mothe. Arquitetura moderna desde 1900 (Porto: Alegre Bookman, 2008.) Translated by Alexandre Salvaterra. 


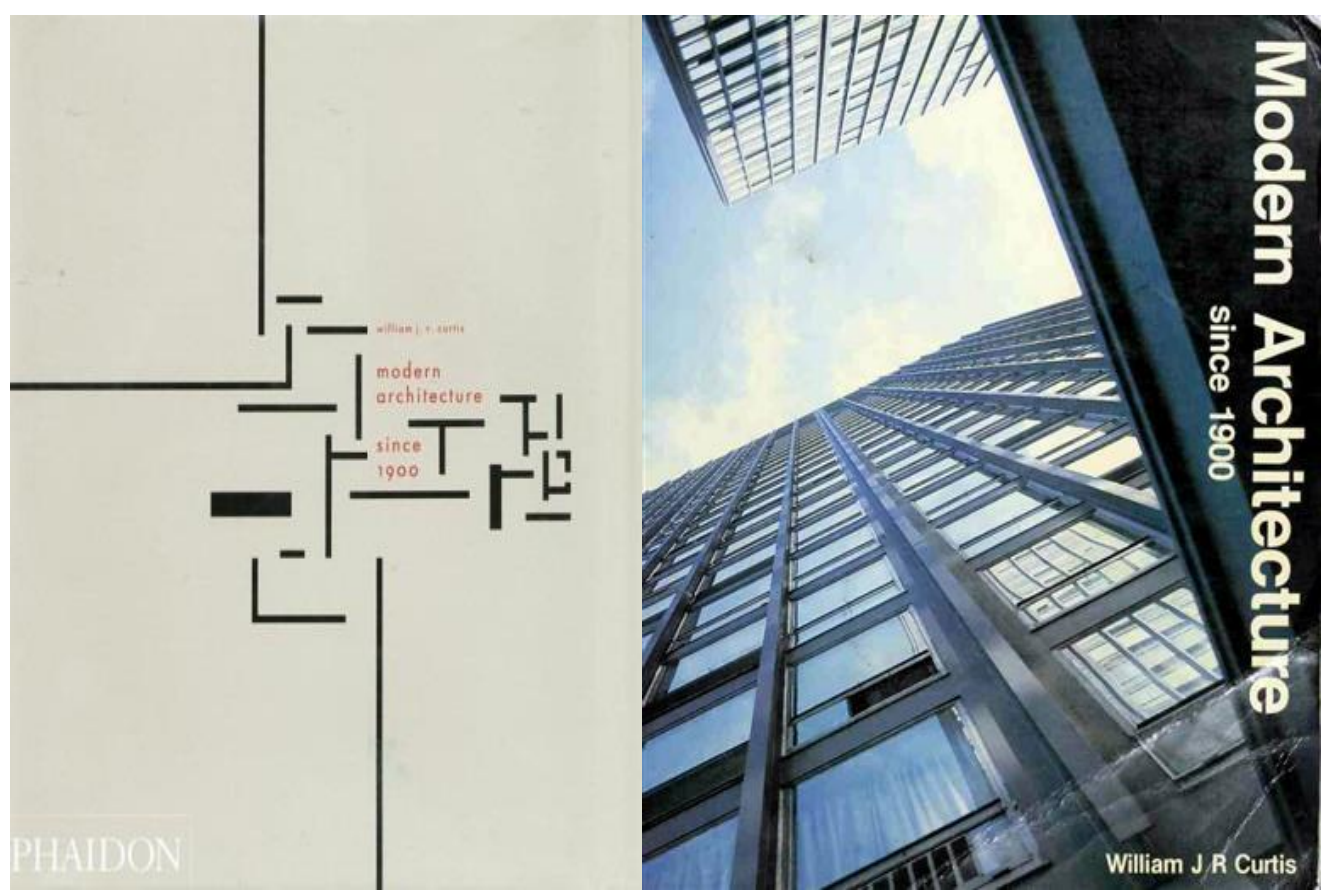

Figure 1. Covers of the 1987 and 1996 Editions of Modern Architecture since 1900

Before attempting to compare the account of Greek modern architecture in all editions in detail, a brief survey of the contents helps to explain the book's structure and its 1996 expansion and reorganisation (Figure 1). The 1982 and 1987 editions were arranged in three parts: Part 1: The Formative Strands of Modern Architecture, Part 2: The Crystallization of Modern Architecture between the Wars, and Part 3: Transformation and Dissemination after 1940. In 1996 Curtis made substantial changes. He added two chapters to the first part: one on the industrial city and the skyscraper and another on national myths and classical transformations, which considers what has been called 'National Romanticism' citing Barcelona, Helsinki, Chicago and Vienna. In the second part, Curtis added a new chapter and reorganised the order of the last chapters. Curtis moved the last chapter in the Part 2 in the 1982 edition "The Continuity of Older Traditions" to follow the chapter on the Villa Savoye, and included the work of Mies van der Rohe to the chapter that earlier focuses on Wright and Le Corbusier in the 1930s. In the 1996 edition, Curtis also reversed the order of tow later chapters so that chapter on the spread of modern architecture in Britain and Scandinavia preceded that on totalitarian critiques of the modern movement. Curtis added a new final chapter in Part 2 entitled "International, National, Regional: the diversity of a New Tradition".

However, 1996 saw greater changes to final third of the 1982 edition. In Part 3, which addresses the transformation and dissemination of modern architecture after 1940, Curtis added two chapters, deleted another and renamed the last four. Between the chapters discussing Alvar Aalto and Louis Kahn, he addressed, first, the "Disjunctions and Continuities in the Europe of the 1950s" and then, "The Process of Absorption: Latin America, Australia, 
Japan". Kahn's chapter was renamed: “On Monuments and Monumentality: Louis I. Kahn". The notion of crisis disappeared from the title of the chapter on the critique in the 1960s and the notion of identity was introduced in the title of the chapter dealing with the developing world. The situation in the 1970s, the recent past of the 1982 edition, is discussed in terms of 'pluralism'. The addendum of the 1987 edition, "The Search of Substance: Recent World Architecture (1987)", was expanded in 1996 into an entire new fourth part dealing with "Continuities and Change in the late twentieth century" in three chapters: "Modern Architecture and Memory: new perceptions of the past", "The Universal and the Local: landscape, climate and culture" and "Technology, Abstraction and Ideas of Nature". The conclusion maintained the title "Modernity, Tradition and Authenticity", but there were additions to its content. A thorough reading of the editions allows us to examine how the reorganisation, the renaming and the additions reveal the development in Curtis' discourse on modern architecture.

\section{Greece in Modern Architecture since 1900}

In the first edition there are four references regarding Greece, two address the figure and work of Le Corbusier, one of Kahn and the last one of Alison and Peter Smithson: firstly, in chapter 8 "Le Corbusier's quest for idea form" when referring to his 'voyage d'Orient' through Italy, Greece and Asia Minor; secondly, in chapter 21 "The Unité d'Habitation at Marseilles as a Collective Housing"; thirdly, in chapter 23 on "Louis I. Kahn and the Challenge of Monumentality"; and lastly, in chapter 24 on "Architecture and Antiarchitecture in England". Surprisingly, Greece is mentioned also as influencing Alvar Aalto, but it does not appear in the index until the third edition. On the contrary, the reference to Kahn's Greek influence disappears from the index in 1996. Apart from two references to Aalto's work, the third edition has two new references to Greece in chapter 21 on "International, National, Regional: the Diversity of a New Tradition" and in chapter 26 on "Disjunctions and Continuities in the Europe of the 1950s".

Greece, in the first edition of Curtis' book, appears mainly as inspiration in the work of Le Corbusier at different stages of his career, of Kahn and of the Smithson. There is no mention of any Greek modern architect or modern building. It is not until the third edition of Modern Architecture that Dimitris Pikionis and his work are mentioned in the context of a 'universalising' modernism. As a result, from the first to the definite edition of the book, there is a shift in the understanding of the position of Greece in the account of the development of modern architecture, from a source of inspiration of modern architects to an example of the struggle to reconcile modernity and tradition.

Le Corbusier's long journey of 1911 was a search for the immutable or perennial values of architecture and resulted in incisive thumbnail sketches. (Figure 2). According to Curtis in the first edition of Modern Architecture, Le Corbusier sketches of traditional architecture -including the white cubic 
dwellings of the Greek coast- helped him "to lock images in his memory". ${ }^{2}$ Le Corbusier's attitude towards the past and tradition goes beyond the copying of forms in an attempt "to cut through to the anatomy of past architecture, to reveal principles of organization and to relate plan shapes to the dynamic and sensuous experience of volumes in sequence and in relation to setting". ${ }^{3}$ Greek, together with Roman and Turkish impressions were "to become part of a rich stock of forms -the stuff of the later Le Corbusier's imagination". 4

But the greatest impression was made by the Acropolis at Athens. He visited the Parthenon every day, sometimes for hours, sketching it from many angles. He was impressed by the strength of the underlying idea, by the sculptural energy, by the precision of the forms (even then he compared the Parthenon to a 'machine') and by the relationship to the site and far distant views of mountain and sea. There was something about the ceremonial procession over rising strata of rock which Jeanneret never forgot. The Parthenon gave him a glimpse of an elusive absolute which continued to haunt him. ${ }^{5}$
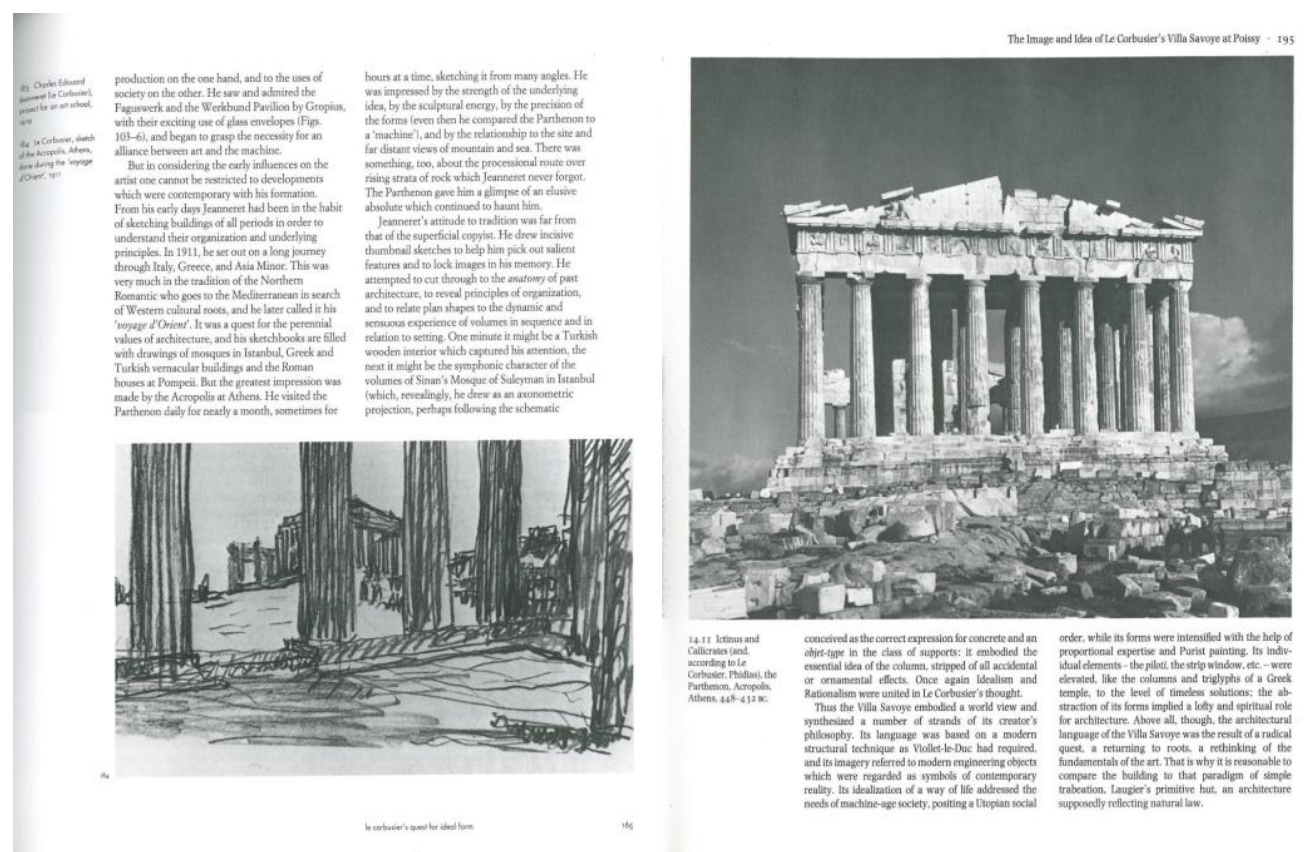

Figure 2. Pages that Refer to Le Corbusier's Voyage d'Orient in the 1987 and 1996 Editions of Modern Architecture since 1900

At the time he was working on the Unité d'Habitation at Marseilles the memories of Greece were still in his mind: "this little acropolis of resounding silent objects in light seems set up to celebrate a healthy balance between the

2. William Curtis, Modern Architecture since 1900 (Englewood Cliffs: Prentice Hall, 1982), 105.

3. Ibid, 106.

4. Ibídem.

5. Ibid, 105. 
mental and the physical". 6 Also in the early nineteen fifties that Louis Kahn stayed at the American Academy in Rome and travelled through Greece and Egypt. In Curtis' opinion, "his sketchbooks of this period suggest he was trying to get back to basics - to probe the central meanings of architecture". " Later on, in the early sixties, the "processional character" of the Economist Cluster's walkway designed by Alison and Peter Smithson "was evidently inspired by a visit to Greece". 8

As mentioned above, even if it does not appear in the index, Greece is also mentioned in a chapter on the work of Alvar Aalto in the first edition of Modern Architecture. Firstly, Curtis discusses the Town Hall in Säynätsalo in terms of egalitarianism and involvement. In his opinion, the curved profile of the benches "recalled Aalto's sketches of the mouldings in Greek theatres" and the rectangular state chamber for council meetings was inspired by "ancient Hellenistic cities such as Miletus or Priene". ${ }^{9}$ Curtis describes the building as casual and civic, not monumental, and as somewhere between the rural and the urban. "In Aalto's private terms it drew together the Greek democratic city in its ruined shaped with the scraped glacial contours of the north." ${ }^{10}$ Secondly, the Helsinki University of Technology in Espoo had nature as a source of 'laws' and was evidence of Aalto's interest in the relationship between the intellectual and the sensual in Greek ancient architecture.

But whereas for the Swiss [Le Corbusier] the Parthenon was the prime example (a 'pure creation of the mind'), for Aalto the chief inspiration lay in the way the Greeks arranged their urban sites with amphitheatres, stadia, and ceremonial platforms linked by paths and routes. It was an 'irregular' order of this kind -in which there was, nonetheless, a harmony of buildings, landscape and the spirit of place- that Aalto managed to evoke in his drawings of antique ruins, especially Delphi, and that he attempted to translate into his own architecture and urban designs. It may be that the final touchstone for the far shape which so obsessed him was the Greek amphitheatre, fractured and eroded by the time. ${ }^{11}$

Modern architecture in Greece is discussed by Curtis in the third edition of Modern Architecture among other countries in a discussion on regionalism, universalism and the development of modern architecture in other parts of the world, apart from America and central Europe. When discussing the relationship between modernity and tradition, Curtis states that "the forms of modern architecture were more likely to marry with some local traditions than with others". It could be added that with those local traditions that had, in fact, influenced modern architecture in the first place, which was the case of Greek 286.

6. William Curtis, Modern Architecture since 1900 (London: Phaidon Press, 1996), 284-
7. Ibid, 310 .
8. Ibid, 320.
9. Ibid, 457.
10. Ibid, $457-458$.
11. Ibid, 461. 
ancient architecture as discussed above. What Curtis characterises as 'Mediterraneanism' and 'Hellenism' in some of Le Corbusier's works in the twenties influenced Greek architects that reject revivalism and embraced modernism before the decade ended. They attempted to root the new international language "in the social habits, spatial patterns and landscape of their own country. Analogies between the cubic white volumes and flat roofs of modern architecture and the vernaculars of the Greek islands were not so hard to make". 12

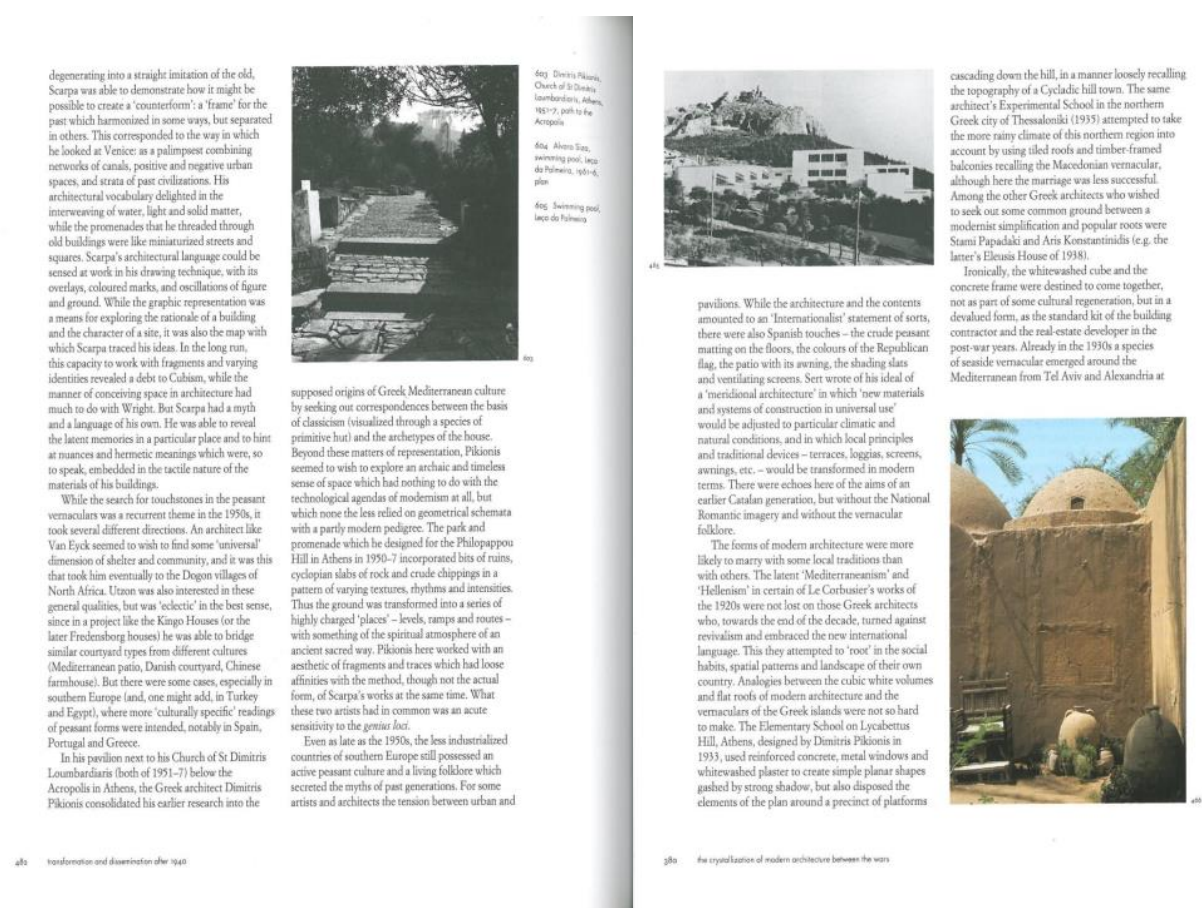

Figure 3. Pages that Refer to the Work of Pikionis in the 1996 Edition of Modern Architecture since 1900

The work of Dimitris Pikionis in the elementary school on Lycabettus Hill in Athens and the experimental school in the north Greek city of Thessaloniki is highlighted by Curtis as an example of this marriage in the decade of the nineteen thirties (Figure 3). Stamo Papadaki (Stami in Curtis' book) and Aris Konstantinidis are referred to as "Greek architects who wished to seek out some common ground between a modernist simplification and popular roots". ${ }^{13}$ Pikionis' work around 1950 and, more generally, Greek architecture together with Spanish and Portuguese are examples of "more 'culturally specific' readings of peasant forms". ${ }^{14}$ In Pikionis' work at that time, with an aesthetic of fragments and traces, Curtis finds a method, not form, similar to Scarpa's, both architects with an acute sensitivity to the genius loci. ${ }^{15}$ The pavilion next

12. William Curtis, Modern Architecture since 1900 (London: Phaidon Press, 1996), 380.

13. Ibídem.

14. Ibid, 482.

15. Ibídem. 
to his Church of St Dimitris Loumbardiaris bellow the Acropolis in Athens, according to Curtis, consolidated Pikionis' "research into the supposed origins of Greek Mediterranean culture by seeking out correspondences between the basis of classicism (visualized through a species of primitive hut) and the archetypes of the house". ${ }^{16}$ The Philopappou Hill in Athens in 1950-7 incorporated bits of ruins, cyclopean slabs of rock and crude chippings in a pattern of varying textures, rythm and intensities and according to Curtis, he wished to explore an archaic and timeless sense of space.

To sum up and as has been discussed above, Curtis does not include works of modern architects from Greece in his account of the development of modern architecture until the third edition of Modern Architecture since 1900.

\section{Authenticity in Regionalism}

During the period of time separating the first and third editions of Modern Architecture, and especially in the late 1980s, not only Curtis but other critics and historians such as Kenneth Frampton and Paul Rudolph published their reflections on the notion of regionalism. Recent studies acknowledge how "lesser-known but equally important contributions to the landscape of critical regionalism are the ideas and the selected projects" by Dimitris and Suzana Antonakakis from Greece, Sedad Hakki Eldem and Turgut Cansever from Turkey, Geoffrey Bawa from Sri Lanka and, of course, Hassan Fathy from Egypt. ${ }^{17}$ In these countries it existed a dialogue between tradition and modernity. Contrary to Dimitris Pikionis, both Geoffrey Bawa and Hassan Fathy are modern architects used by Curtis in his discussion of what he calls 'authentic' regionalism. Paul Ricœur's formulation of the 'developing world' bring together the analysis of Pikionis' work in Modern Architecture and the reflection on authentic regionalism, both undertaken by Curtis at this time. Paul Ricœur's formulation of the 'developing world' had also been used by Kenneth Frampton in his search towards a critical regionalism:

Whence the paradox: on the one hand, it has to root itself in the soil of its past, forge a national spirit, and unfurl this spiritual and cultural reivindication [sic] before the colonialist's personality. But in order to take part in modern civilisation, it is necessary at the same time to take part in scientific, technical, and political rationality, something which very often requires the pure and simple abandon of a whole cultural past. It is a fact: every culture cannot sustain and absorb the shock of modern civilisation.

16. William Curtis, Modern Architecture since 1900 (London: Phaidon Press, 1996), 482.

17. Fikret Yegul, "Hercules at the Roundabout: Multidisciplinary Choice in the History of Architecture," in Rethinking Architectural Historiography, ed. D. Arnold, Elvan Altan Ergut and Belgin Tura Ozkaya. (London and New York: Routledge, 2006). 
There is a paradox: how to become modern and return to sources; how to revive an old, dormant civilisation and take part in universal civilisation. ${ }^{18}$

Curtis formulation of regionalism around 1985 is presented in the same terms as the account of the development of modern architecture in Third World countries, which he was preparing for the subsequent editions of Modern Architecture (Figure 4). Curtis places the notions of modernity, tradition, identity and authenticity at the core of his research. At that time, identity was being re-interpreted as a result of a new general human order in relation to the territory, new understanding of politics, of beliefs; in summary, as a result of new cultural paradigm. Post-colonialism, secularization and the new selfconfidence of non-western countries had on effect on the architecture -as on any other artistic and cultural product- of not only those countries. In Curtis' opinion, regionalism is not a marginal phenomenon affecting only Third World countries but a universal one and, thus, needs to be subject to an analysis based "on a sound philosophical basis. (...)Nonetheless I [Curtis] feel there is a requirement for cleaning up the house of ideas and for laying the basis for theory". 19

Having characterised regionalism as hazy, Curtis tries to shed some light on the notion and defines it in terms of balance or hybrids between struggling realities: urban and rural, industrial and artisan, the 'uprootedness of the metropolis' and peasant values, modernity and tradition, imported international and indigenous, transient and immutable. An architect that wants to produce an authentic regionalist work of architecture, according to Curtis, acknowledges these dichotomies from an understanding of the new conditions of universal interchange and interdependence that already characterise the world in the 1980s. He claims that there is more than one way to read local tradition, but regionalists attempt to see the type, the general rule, the originating principle. An architect that wants to produce an authentic work of architecture, then, would absorb the generating principles and structures of the past, go beyond the surface and incorporate "memories, myths and aspirations that five a society coherence and energy". ${ }^{20}$ Having done that, the next step would be to give form to those principles and aspirations in a building that provides an 'authentic' expression. Curtis defines this process in terms of cultural excavation and going back to his definition of authenticity, it is through this process that the architect would produce buildings with that certain timeless

18. Kenneth Frampton, "Towards a Critical Regionalism: Six Points for an Architecture of Resistance," in The Anti-Aesthetic: Essays on Post-Modern Culture, ed. Hal Foster (Seattle: Bay Press, 1983), 16. Also found in Curtis, "Regionalism in Architecture Session III," in Regionalism in Architecture, ed. Robert Powell (Singapore: Concept Media/The Aga Khan Award for Architecture, 1985) 73. Both quoted from: Paul Ricœur, History and Truth (Evanston: Northwestern University Press, 1965), 276-277.

19. Curtis, "Regionalism in Architecture Session III," in Regionalism in Architecture, ed. Robert Powell (Singapore: Concept Media/The Aga Khan Award for Architecture, 1985), 73.

20. Curtis, "Towards an Authentic Regionalism," in Mimar 19: Architecture in Development, ed. Hasan-Uddin Khan. (Singapore: Concept Media, 1986), 24-31. 
character fusing old and new and come up with pattern languages and common usages or vernaculars of the past.

Just as traditionalism is a reaction against loss of continuity, so regionalism is a restorative philosophy in favour of supposed raw harmony between people, their artefacts and nature Regionalism is not likely to appeal to the blatant technocrat, nor to the parvenu who recalls that working in fields for twelve hours a day in exchange for virtually nothing may not be the ideal life. Regionalist yearnings are especially appealing to sensitive intellectuals who are troubled by the fragmentation that seems to come with industrialization, but who also wish to maintain the mobility, complexity of viewpoint and even wealth that industrialism affords. ${ }^{21}$

According to Curtis, regionalists understands the past, that is tradition, in terms of layers: layers of inventions superimposed and layers to unravel to see how, on the one hand, the vernacular has been transformed by the foreign and, on the other, how the foreign has been adapted to the existing. Curtis introduces an interesting nuance in his discussion adding the possibility of transformation -present also in Modern Architecture since 1900. By fusing new and old, the new is transformed by the old and the old transformed by the new. And again, the challenge is to maintain the trend and find a right balance between local, national and international. And how do you achieve the balance? As has been mentioned before, Curtis rejects to provide a checklist to detect authenticity in architecture, but he claims that "'authentic regionalism' stands out against all hackneyed and devalued versions of culture, whether these come from the international economic order, from nationalist propaganda, or, more recently, from pan-Islamic clichés". ${ }^{22}$

In Curtis's argument the modern, urban, transient and imported is embodied in the 1980s understanding of the tradition (also, tradition) of the International Style. He defends that traditional structures, once understood and interiorise by the architect, not manipulated; would be blended with only the best of the modern tradition, not with the worst. His judgment can be understood as both a defence of modern architecture and a critique of the arbitrariness and superficiality of post-modernism. He defends that through a rigorous understanding of the past and the vernacular is the path towards a nonarbitrary architecture.

It seemed as if the concrete frame and the air-conditioner were together conspiring to demolish local identity from architecture altogether. Understandably such buildings have been targeted as instruments of neocolonialism and urban destruction, the opposite of traditional values of any kind. This may be true but the answer does not lie in just changing the historical clothes of industrial buildings or in just pretending that

21. Curtis, "Regionalism in Architecture Session III," in Regionalism in Architecture, ed. Robert Powell. (Singapore: Concept Media/The Aga Khan Award for Architecture, 1985), 74.

22. Ibídem. 
modernization will go away. Nor will anything of lasting value be created if Third World architectural beliefs simply pick up the latest fashionable tricks from the United States and Western Europe. Post-modernism is part of the disease, not the cure since it reduces the problem of tradition to a trivial manipulation of signs and references and since its trendy aestheticism masks a cynical and reactionary cultural stance. ${ }^{23}$

What is the result of this fusion of old and new, rural and urban, etc.? For Curtis that is 'true', 'authentic' and he explains clearly what authentic regionalism is not: it is not a mere copy of vernacular or pastiches of national cultural stereotypes. In forgetting about the problem of style, the regionalist would achieve an authentic work of architecture that translates immutable principles into a thoroughly modern and that will be added to the stock of cultural memories and would be modern and ancient at the same time. According to Curtis, the regionalist would search for basic values and types well-suited to locale and to climate, and this does not imply necessarily regression or nostalgia. However, it is not only about buildings and local conditions, but also about articulating the philosophy that would address the transformations "from rural and traditional to modern and imported. The former need preserving, or, when new commissions emerge, re-invigorating; the latter need to be 'regionalised' but at a level that is much deeper than stylistic or ornamental adornment". ${ }^{24}$
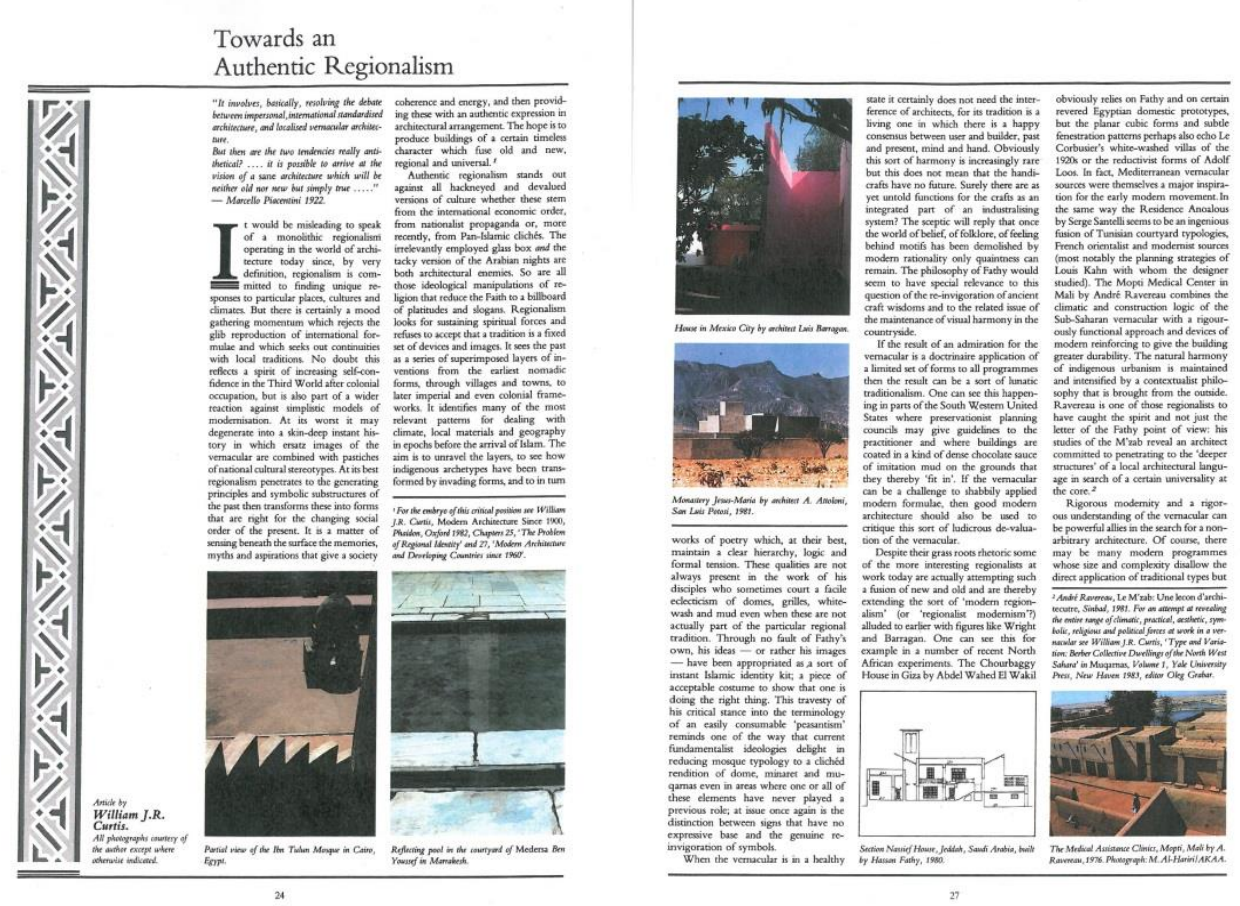

Figure 4. Pages of "Towards an Authentic Regionalism"

23. Curtis, Towards an Authentic Regionalism, 26.

24. Ibid, 25. 
According to Peter Serenyi in his review of the book, in Curtis' "treatment of regional developments the author deals with the question of authenticity most convincingly in connection with the architecture of the developing". ${ }^{25}$ It is through the notion of 'authentic' regionalism and the blending or fusion of old and new that the consideration of architecture of non-western countries shifts from being a source of inspiration to being an authentic modern architecture. As tradition is used by Curtis both to refer to regional and international, in a way, the dichotomy between tradition and modernity disappears. At this point it is important to remember that Curtis defines modernity as a tradition that transforms and that is transformed. Compared to the Parthenon, Greek modern architecture and Dimitri Pikionis's work are just as valid and authentic as sources of inspiration for contemporary architecture. In conclusion, tradition and modernity for Curtis are not opposed notions. This was made very clear in the third World and post-colonial countries being analysed at that time through the lens of regionalism.

\section{Towards an Authentic Universalism}

This conception of regionalism was hardly new at the end of the twentieth century. As early as 1922, Marcello Piacenti -an Italian architect- rejected the use of international and vernacular as opposed qualifiers for architecture allowing Curtis to claim his rejection towards the opposition of modernity to tradition:

'It involves', he says, 'basically resolving the debate between impersonal, international, standardised architecture and localised vernacular architecture. Are the two tendencies really antithetical? Is it possible to arrive at a vision of sane architecture, which will be neither old nor new, but simply true?' I think that it is worthwhile to reflect on that specially give a certain style of thought, which insists on opposing modernity to tradition. This opposition arises from a false understanding of both ideas. The best within modernism can be profoundly rooted in tradition; and the best in tradition is to do with a dynamic process of rethinking certain central kernel ideas. ${ }^{26}$

And immediately after, in the decade of the thirties, it was the early historiography of modern architecture setting its aims and objectives in the writing of what was happening in modern architecture. In the third edition of Modern Architecture, Curtis blames early histories and historians of formulating a 'misunderstood' account of modern architecture. Alberto Sartoris, Emil Kaufmann, Henry-Russell Hitchcock, Philip Johnson, Walter Curt Behrendt, Nikolaus Pevsner, Lewis Mumford and Sigfried Giedion built

25. Peter Serenyi, "Review of Modern Architecture since 1900," Journal of the Society of Architectural Historians 43, no.3 (1984): 275.

26. Curtis, Regionalism in Architecture Session III, 73. 
genealogies and lineages for modern architecture relying mostly on their personal preferences and different theories about history. "Inevitably the early accounts reproduced some of the rhetoric that modern architects themselves used to promote themselves used to promote and defend their own work; inevitably too they reflected the biases, allegiances, even geographical situation of their authors." 27 Giedion's writings at this time are harshly criticised by Curtis for having ignored regionalist or classicizing influences in the formation and development of the work of the so called modern masters.

Stanislaus von Moos argues that the chapter on "Modern Architecture and Developing Countries since 1960" is "among the most interesting [chapters] although here the limitations of the author's idiosyncratically aesthetic point of view are most clearly felt". ${ }^{28}$ In the first edition of Modern Architecture, in 1982, fifty years later, Curtis in completing the account of the development of modern architecture ignores, or fails to include, the work of Dimitris Pikionis and modern architecture in Greece. It was not until the third edition of Modern Architecture that Curtis presented Greece among other countries like Turkey, not as inspiration in the work of modern masters, but as producing authentic and modern works of architecture. It was not until 1996 and the last edition of the book, that he provides readers and students with an 'authentic' account of the development of modern architecture beyond the Western perspective, placing authenticity and a sense of universalism at the core of his research.

It is not unreasonable to posit a 'universalizing' aspect to modernism in this period, so long as some strips away the Western bias and progressive assumptions which lurk behind this formulation, and so long as one also takes into account national and regional histories with their own logic and momentum. In the 1930 s there was a species of 'cross-fertilization' in which modern architecture was drawn into a variety of local agendas, an in which regional preoccupations were also given an international stamp. Sometimes the new simply collided with the old; sometimes there was mutual transformation. Modern forms made a break with what had gone immediately before, but they also allowed the substructures of national or regional cultures to be understood in new ways. ${ }^{29}$

\section{Bibliography}

Arnold, Dana, Elvan Altan Ergut and Belgin Tura Özkaya, ed. Rethinking Architectural Historiography. London and New York: Routledge, 2006.

Curtis, William. Modern Architecture since 1900. Englewood Cliffs, NJ: Prentice Hall, 1982.

27. Curtis, Modern Architecture since 1900, 372.

28. Stanislaus Von Moos, "Revising Modernist History: The Architecture of the 1920s and 1930s (Summer)," in Review of Modern Architecture since 1900. Art Journal 43, no. 2 (1983): 208.

29. Curtis, Modern Architecture since 1900, 372. 
. "Regionalism in Architecture Session III." In Regionalism in Architecture. Edited by Robert Powell. Singapore: Concept Media/The Aga Khan Award for Architecture, 1985.

"Towards an Authentic Regionalism." In Mimar 19: Architecture in Development. Edited by Hasan-Uddin Khan. Singapore: Concept Media, 1986: 24-31.

Modern Architecture since 1900. London: Phaidon Press Limited, 1987. [Since this edition added just an addendum at the end, it has been used in this paper when referencing the first edition (1982)]. . Modern Architecture since 1900. London: Phaidon Press Limited, 1996.

Frampton, Kenneth. "Towards a Critical Regionalism: Six Point for an Architecture of Resistance." In The Anti-Aesthetic: Essays on Post-Modern Culture. Edited by Hal Foster. Seattle: Bay Press, 1983:16-30. "Prospects for a Critical Regionalism." Perspecta 20. 1983: 147-162.

Ricœur, Paul. History and Truth. Evanston: Northwestern University Press, 1965.

Serenyi, Peter. "Review of Modern Architecture since 1900." Journal of the Society of Architectural Historians 43, no.3 (1984): 274-277.

Von Moos, Stanislaus. "Revising Modernist History: The Architecture of the 1920s and 1930s (Summer)." In Review of Modern Architecture since 1900. Art Journal 43, no. 2 (1983): 207-209.

Yegul, Fikret. "Hercules at the Roundabout: Multidisciplinary Choice in the History of Architecture." In Rethinking Architectural Historiography. Edited by D. Arnold, Elvan Altan Ergut and Belgin Tura Ozkaya. London and New York: Routledge, 2006. 